\title{
金電析皮膜におよぼす高電流パルスの影響
}

\author{
岩 城 泰 彦*, 荒 巻 芳 幸*
}

\section{Effect of High Pulsed Current on Gold Deposits}

\author{
Yasuhiko IW AKI* and Yoshiyuki AR AM AKI*
}

\begin{abstract}
The effect of high pulsed crrent on the properties of electrodeposited gold film was investigated. The deposits were analyzed by means of an electron microscope and X-ray diffraction, and it was found that the corrosion resistance of gold films was far better when formed by high pulsed current than when formed by direct current.
\end{abstract}

Key Words : Pulsed Current, Corrosion, Gold Deposition

\section{1. 緒言}

電子工業の発達に伴い, 貴金属めっきの電子部品への 需要が急速に伸びて拈り, 高信頼性が望まれている。金 めっきコネクターへ要求される機能としては, 析出皮膜 の外観, 密着性, 電気伝導性, 耐食性执よび耐摩耗性な

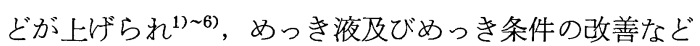
数多くの研究がなされている。めっき条件の改善の $1 つ$ として, 近年直流に代わるハルス電流の適用が試みられ ている(7) 11) が，そのほとんどが平均電流密度 $3 \mathrm{~A} / \mathrm{dm}^{2}$ 以下の低電流密度で行われているにすぎない。

そこで本研究では, 酸性金めっき液中に括いて高電流 密度で得られたハルスめっき皮膜の特性について表面状 態と構造抌よび耐食性などから検討を行った。

\section{2. 方法}

\section{1 めっき条件}

めっき液は, $\mathrm{KAu}(\mathrm{CN})_{2}(\mathrm{Au} と し て 15 \mathrm{~g} / \mathrm{L})$, クェン 酸として $200 \mathrm{~g} / \mathrm{L}$ を添加し, $\mathrm{pH}$ は $\mathrm{KOH}$ にて調整を行 い3.5とした。

また硬化剤として硫酸コバルト（Co として $0.2 \mathrm{~g} / \mathrm{L})$ を添加した。薬品は, すべて試薬 1 級を用いイオン交換 水にて建浴した。めっき装置は, 小型ノズル噴射装置を 用い, 流量を $0.9 \mathrm{~m}^{3} / \mathrm{h}$ ，ノズル径を $10 \mathrm{~mm}$ とした。ま た液晶は $60^{\circ} \mathrm{C}$ 一定とした。陰極は厚さ $0.3 \mathrm{~mm}$, 大きさ $15.5 \times 100 \mathrm{~mm}$ のりん青銅材（C5210）に, ニッヶルを 1-2 $\mu \mathrm{m}$ めっきして用いた。陽極は, ニオブ上の白金ク ラッド材を用いた。電源は, 藤電気工業秼製ハルス電源 を用い, 定電流バルスにて平均電流密度 $\left(i_{\mathrm{av}}\right) 5 ， 15$, および $25 \mathrm{~A} / \mathrm{dm}^{2}$, ON time ( $T_{\text {on }}$ )を $1 \mathrm{~ms} \sim 30 \mathrm{~ms}$, duty

* 山王鍍金(侏) (广223 神奈川県横浜市港北区綱島東5-8-8) Sanno Plating Co., Ltd. (8-8, Tsunashimahigashi 5 chome, Kohoku-ku, Yokohama-shi, Kanagawa 223) cycle $(\theta)$ を20\%か $580 \%$ 範囲で変化させ, $0.5 \mu \mathrm{m}$ の 厚さにめっきした。

\section{2 表面形態と構造}

金めっき皮膜の形態及び構造は電子顕微鏡（日本電子 (侏製 JXA-8600 M) 拉よびフィリップ社製 $(\mathrm{PW}-1700)$ $X$ 線回折装置を用いて調査した。

\section{3 而食性試験}

耐食性試験として, E.C 試験法 ${ }^{12), 13)}$ (Electrolytic Corrosion Test) により, めっき金属を溶解させ, 電解 液中に溶出したニッケルを原子吸光にて測定して, その

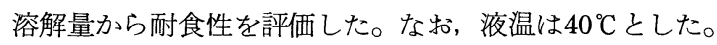

\section{3. 結果及び考察}

\section{1 金析出皮膜の表面形態および配向性}

図 1 は, 析出状態に与えるパルスパラメーターの影響 を示したものである。一般的に $\theta$ が低く， $T_{\text {on }}$ が長いほ ど拡散層内に拈けるイオンの久乏が起こるために表面状

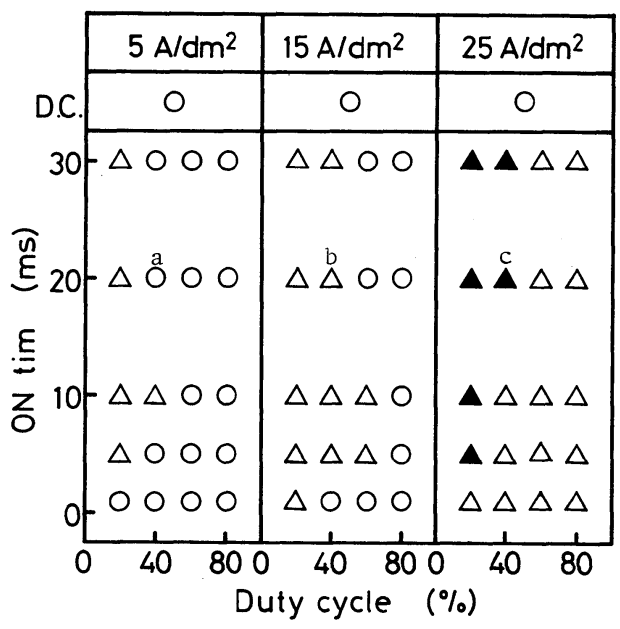

Fig. 1 Effect of pulse parameter on appearance. $\mathrm{a}$ : britht, b : semi-bright, $\mathrm{c}:$ dull 


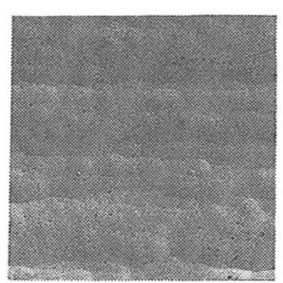

D.C.

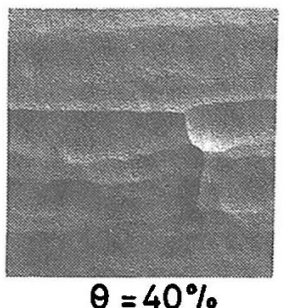

Ton $=1 \mathrm{~ms}$

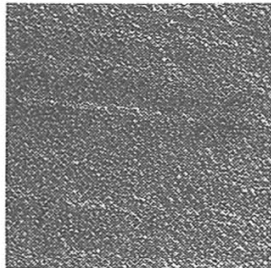

$\theta=20 \%$

Ton $=1 \mathrm{~ms}$

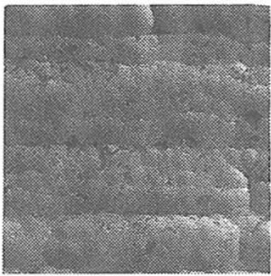

$\theta=60 \%$

Ton $=1 \mathrm{~ms}$

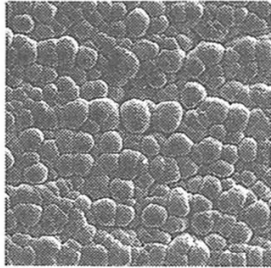

$\theta=20 \%$

Ton $=10 \mathrm{~ms}$

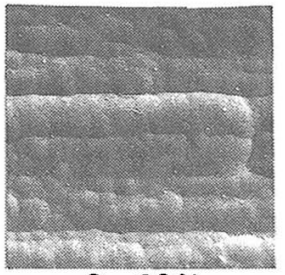

$\theta=80 \%$

Ton $=1 \mathrm{~ms}$

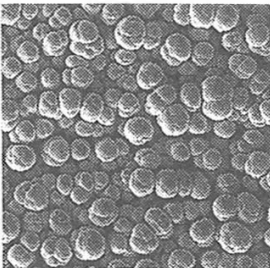

$\theta=20 \%$

Ton $=30 \mathrm{~ms}$

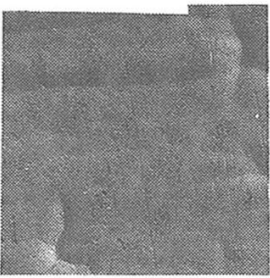

$\theta=80 \%$

Ton $=30 \mathrm{~ms}$

Fig. 2 Effect of pulse parameter on gold deposit. $i_{\mathrm{av}}=25 \mathrm{~A} / \mathrm{dm}^{2}$

$10 \mu \mathrm{m}$

態は悪く, 焦げ状の褐色析出物が認められた。ハルス電 流による表面状態は $i_{\mathrm{av}} 5-15 \mathrm{~A} / \mathrm{dm}^{2}$ においては直流の 場合よりる無光沢であった。

$i_{\mathrm{av}} 25 \mathrm{~A} / \mathrm{dm}^{2}$ にて得られた SEM 像を図 2 に示した。 $\theta 20 \%$ 一定に拈いて， $T_{\text {on }} 1 \mathrm{~ms}$ の場合, $0.1 \sim 0.3 \mu \mathrm{m}$ の 微細結晶が観察されるが， $T_{\text {on }} 10 \mathrm{~ms}$ 以上では結晶径仕 $3 \sim 5 \mu \mathrm{m}$ と大きくなり，粗結晶の傾向が見られる。また， $T_{\text {on }}$ が小さい場合 $(1,5 \mathrm{~ms})$ 表面形態に与六る $\theta$ の影響 は見られないが， $\theta$ 扰よび $T_{\text {on }}$ が共に大きい場合 $(\theta 80$ $\left.\%: T_{\text {on }} 30 \mathrm{~ms}\right)$ kは滑らかな表面を呈していた。

（111）面の優先配向に特よぼすバルスバラメーター の影響を図 3 に示した。（111）面体優先配向は $\theta$ 20 $40 \% ， T_{\mathrm{on}} 1 \sim 5 \mathrm{~ms}$ に物いて特に顕著であったが，一般 に $\theta$ 执よび $\mathrm{T}_{\text {on }}$ の増加にしたがって隇少し，（222）面 への配向が強くなる傾向が見られた。

\section{2 金電析皮膜の耐食性}

金めっき皮膜の耐食性に招よぼすバルスバラメーター の影響を图 4 に示した。直流およびバルス共に電流密度 が低いほど耐食性に優れた皮膜であった。 $i_{\mathrm{av}} 5 \mathrm{~A} / \mathrm{dm}^{2}$ に晾る皮膜の耐食性は直流の場合より劣る条件が見ら れる。しかし， $i_{\mathrm{av}} 15 \mathrm{~A} / \mathrm{dm}^{2}$ 以上の高電流密度に扎いて は直流の場合よりる優れていた。

高電流密度で得られた金皮膜の耐食性はすでに低電流 密度で報告 ${ }^{10}$ されているよ5に $\theta$ の低い条件下で良好 であった。さらに $\theta$ が大であっても $T_{\text {on }}$ が小さい条件 下で耐食性に優九た皮膜が得られた。耐食性の改善はバ ルス電流による多孔率の減少に起因しているすのと考え られた。

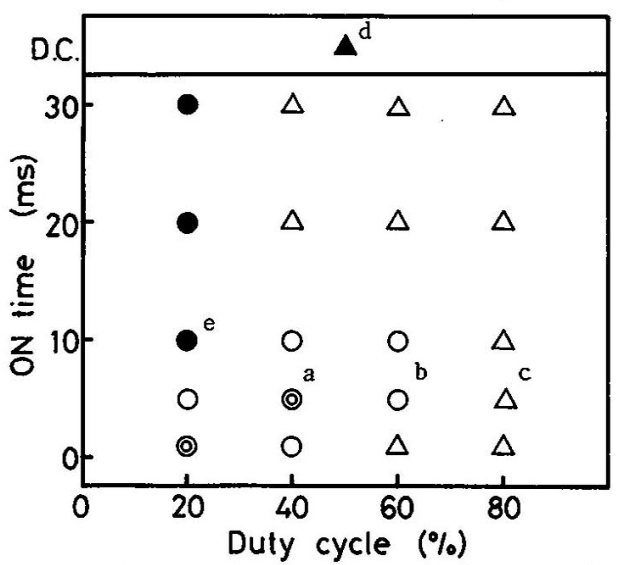

Fig. 3 Effect of pulse parameter on (111) preferred orientation.

Relative intensity : $a>b>c>d>e$

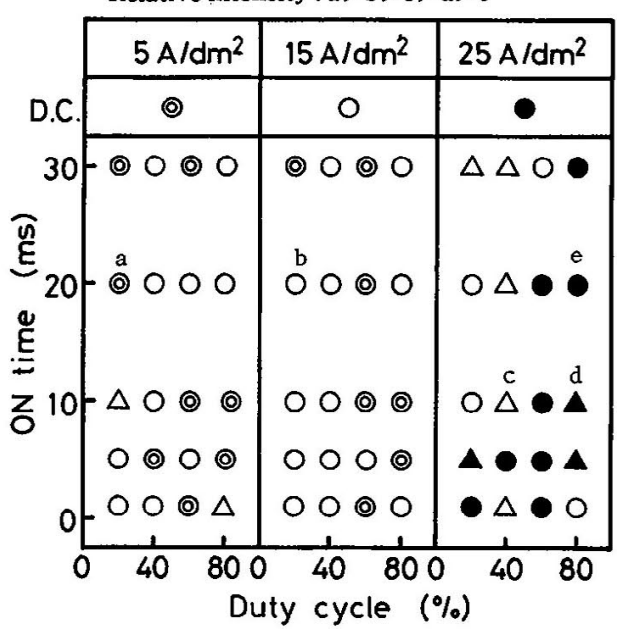

Fig. 4 Effect of pulse parameter on corrosion resistance. $i_{\mathrm{a} \varphi}=25 \mathrm{~A} / \mathrm{dm}^{2}$, corrosion resistance $: \mathrm{a}>\mathrm{b}>\mathrm{c}>\mathrm{d}>\mathrm{e}$ 


\section{4. 結}

論

酸性金めっき溶液中に扣いて高電流密度のハルルス電流 によって得られた金析出皮膜の特性について検討した。 特に高電流密度ハルスによる皮膜の耐食性は直流の場合 よりも優れているが，外観などを考慮するとハルスの実 用化にあたってはさらに電析の諸条件ならびに他の機能 面についても詳細に調査する必要があると思われる。

(1987-12-11受理)

\section{文献}

1）沖中 裕; 金属表面技術，32，500（1981）

2) A. Knodler ; Metalloberflache, 28, 465 (1974)

3) Ch.J. Raub, A. Knodler, J. Lendvay ; Plating, 63, 35 (1976)
4) P. Wlkinson ; Trans. Inst. Metal Finishing, 59, 57 (1981)

5) F.H. Reid, W. Goldie ; Gold plating Technology (Electrochemical Publication Limited, 1974)

6) L. Holt ; Trans. Inst. Metal Finishing, 51, 134 (1973)

7) M. Viswanathan, CH.J. Raub ; Surface Technology, 4, 339 (1976)

8) J. Horkans, L.T. Romakiv ; J. Electrochem. Soc, 124, 1499 (1977)

9) N. Ibl ; Surface Technology, 10, 81 (1981)

10）斉藤い注え，一色洋二，土井 正; 東京都立工業技術セン タ一研究報告, 15，111（1986）

11) Laroche. M.A, Mortier F. Sutter B, Vasseur. G ; Galvano Organo, 53, 935 (1984)

12) R.L.Saur ; Plating, 53, 35 (1966)

13) R.L.Saur ; Plating,53, 1124 (1966) 